\title{
Plant breeding is the last shot in privatization locker
}

London

After several months' delay, the British government last week put up for sale its institutes for the development and marketing of new varieties of plants. The plant breeding assets of the Plant Breeding Institute (PBI) and the National Seed Development Organisation (NSDO) are to be sold as a single package to the highest bidder who can satisfy the government that it is "committed to the continuation of plant breeding relevant to UK agriculture and horticulture". But the delay, blamed on "special considerations" of splitting PBI, could have jeopardized the government's plans. The major opposition parties, Labour and the SDP/Liberal Alliance, said last week that if they were in power after the general election on 11 June they would halt the sale.

If the sale does go ahead, PBI's plant science programmes will become part of a new Institute of Plant Science Research to be established by the Agricultural and Food Research Council (AFRC). The NSDO workforce of 70 and half PBI's staff of 250 will transfer to the private

\section{New UK plant lab}

\section{London}

Twyford Plant Laboratories, the horticultural products company based in Somerset, England, is to invest $£ 6$ million in a new plant biotechnology laboratory to be built in the Cambridge Science Park. The 35 or so scientists at the new facility will undertake fundamental research, in the molecular plant sciences with the aim of developing new products and services for the horticultural sector. Specific research areas will include improved diagnostic methods for plant disease, genetic engineering of plants to make them resistant to insect and pathogen attack, and the creation of novelty variation in ornamentals.

Work on the new building, with 1,300 square metres of laboratory space and a sophisticated greenhouse, is expected to start in June, and the facility should open early in 1988. Since 1982, Twyford has specialized in the supply of plants propagated by tissue-culture methods to growers worldwide, as well as providing plant health services. Numbers employed at their Somerset headquarters have increased by over 200 in the past four years, and turnover now exceeds US\$12 million. In siting the new laboratories in Cambridge, the company hopes to benefit from collaboration with local centres of excellence in molecular biology and in plant breeding and genetic manipulation.

Giles Courtice company. PBI's rapidly expanding oilseed rape programme will not be included in the deal, but will go to the Agricultural Genetics Company (AGC) in settlement of various claims $\mathrm{AGC}$ has on the institute. AGC, a private company, was set up in 1983 and given the first option to exploit plant biotechnology discoveries made by AFRC. AFRC will receive royalties on any new varieties produced.

The announcement last July of the government's plans to sell PBI was roundly condemned by the staff, who felt that the special link between the breeders and molecular biologists would be broken (see Nature 326, 822; 1987).

More than 80 per cent of NSDO's revenue is derived from royalties on varieties produced by PBI. In 1985-86, NSDO earned the government $£ 6$ million in royalties and profits. Given that PBI operated during the same period on an AFRC grant of $£ 3$ million, with a further $£ 1$ million from other sources, PBI fails to see why it cannot be allowed simply to finance itself. It assumes it is being sacrificed for the dogma of privatization.

PBI staff are unhappy at the way the sale is being handled by governmentappointed merchant bankers Lazard Brothers. Potential buyers will be issued with a confidential memorandum of information; on the original timetable, a short-list will be drawn up in July, with the final purchaser selected by August, and the sale completed by September. Until the plant science programmes re-locate in March 1990, the private and public sectors will work on the same site. Offices and laboratory space will be moved as far apart as possible; the locks on the greenhouses will be changed - one kind for the private sector breeders, another for the public sector scientists. It is this kind of enforced segregation that has left many staff feeling bitter. "This is one of the most difficult and damaging aspects of the whole thing. For 75 years we have been trying to make science and breeding work together profitably and now we have to drag them apart", a senior staff member said. Staff are also unhappy at not being allowed to see the memorandum of information.

The government has refused to indicate the sort of price it expects the package, including 400 acres of land, to fetch. Unofficial estimates vary from $£ 20$ million to $£ 70$ million. Imperial Chemical Industries (ICI) and AGC have expressed an interest, and a four-man management team from NSDO and PBI will be hoping to put together a management buy-out, but their chances of success must be slim.

Simon Hadlington

\section{Name change to recognize Levich's contribution}

New York

$D_{R}$ Benjamin Levich, once the highest ranking Jewish refusnik scientist in the Soviet Union, and latterly a holder of one of the five Albert Einstein professorships at the City University of New York (CUNY), will be permanently commemorated at New York City College - the CUNY campus where he taught in his last years. City College's Institute of Physico-Chemical Hydrodynamics, which was established in 1979, when Levich came to New York, and which has from the beginning been known informally as "Levich's institute", is now to bear his name officially. This change of name was announced last week at a memorial colloquium for Levich, who died earlier this year.

The "Benjamin G. Levich Institute of Physico-Chemical Hydrodynamics" will continue working in the field pioneered by Levich, which relates the physical properties of a flow to the chemical processes taking place in it. As the papers presented at the colloquium showed, Levich's research sparked interest in aspects of the subject ranging from helicity on vortex flows to the transport phenomena of twophase systems and to the reflection of pulses from random media - a subject with significance for seismic surveying.

Just 10 years ago, far from commemorating Levich's name in the field for which he had done so much for Soviet science, the Moscow authorities set about removing his name from the literature altogether. Not only were his books withdrawn from circulation, but references to his work were excised from Soviet publications - and his name was blanked out from articles in Western journals before photocopies were distributed. This unusually severe reaction was probably because of his position as a corresponding member of the Soviet Academy of Sciences.

In 1977, when Levich was 65 - a birthday which in normal circumstances would have been honoured by a special conference in the Soviet Union - his colleagues and supporters abroad decided to hold a birthday conference in absentia in Oxford. This proved so successful, from the scientific point of view, that it was decided to hold regular biennial Levich Conferences in physico-chemical hydrodynamics.

When he was eventually granted permission to emigrate, Levich accepted a professorship at Tel Aviv University, Levich supervised research both in Tel Aviv and at City College, and the link between the two institutions will continue at least for a time, as his son, Dr Evgenii Levich, also has academic commitments to both.

Vera Rich 